\title{
Performance Estimation of Solar Flat Plate Air Heating System Using Helical Tapes
}

\author{
Jeson Wilson John* and Ashwin Harikrishnan
}

VIT University, Brahamapuram, Vellore, 632014, India

\begin{abstract}
Solar flat plate collectors (FPC) are used for heating spaces, water heating, and many other purposes. The present technology of solar flat collectors uses vertical fins. The solar flat plate collector having absorber with vertical fins is provided with a helical tape in the fluid flow path. The absorber plate in the solar flat plate collector has an area of 100 $\mathrm{cm} \times 50 \mathrm{~cm}$. The solar flat plate collector has nine ducts with an area of $27.5 \mathrm{~cm} \times 9.5 \mathrm{~cm}$ each. The helical tapes attached have a start angle of $64 \mathrm{deg}$ which pass along the whole length of the duct. The helical tapes have a crosssection area of $1.5 \mathrm{~mm} \times 4 \mathrm{~mm}$. The pitch of the helical tapes is $100 \mathrm{~mm}$. These fins have been attached between the vertical fins of the thickness of $1 \mathrm{~mm}$ and a height of $10.5 \mathrm{~cm}$. Data such as inlet temperature, outlet temperature efficiency and convective heat transfer coefficient are calculated. The mass flow rate of air is $10.28 \mathrm{~kg} / \mathrm{s}$ and the air is subjected to solar radiation between $628.98 \mathrm{~W} / \mathrm{m} 2$ and $708.59 \mathrm{~W} / \mathrm{m} 2$. The values are noted down, and the and the efficiency is noted to have a $10 \%$ rise. The effectiveness of the solar plate collector will increase using a helical fin. A comparative analysis will be done between the conventional flat plate collector and the setup with the helical tapes. The study will show that the helical tapes in flat plate collector will be the best alternative compared to conventional flat plate collector.
\end{abstract}

Keywords: Solar flat collector, Absorber channel, Vertical fins, Helical tapes, Performance enhancement.

\section{INTRODUCTION}

Solar Energy is a very promising and upcoming field in the present world. Nowadays for heating air or water, solar flat plate collectors are used. Fossil fuels are used extensively to heat air and water to generate electricity. But in recent years, the electricity produced in this way has damaged the environment and very erratic. Hence, heating of air and water can be done using solar energy. In this project, we will be focusing our concentration on solar air heaters. There are two types of solar air heaters: Passive and active. Passive solar air heating systems are the systems which rely on heat-absorbing materials like fins, position, and tilt of glass plate and other parameters. Active solar air heating system uses a solar panel which collects heat from the sun. We are planning to change the geometry of the fin.

There are different types of ways that the air can be distributed to various positions of the collector. In the back-pass and front-pass, the air is allowed to enter the front and back of the collector. In the combination layout both the front and back pass is used to together. In the through-pass convective heat transfer, the air is ducted onto one side and, made to pass through a perforated material. The perforated material is the best addition and is the best distributor. The perforated or

*Address correspondence to this author at the VIT University, Brahamapuram, Vellore, 632014, India; Tel: 00919087025956;

E-mail:jesonwilsonj@gmail.com fibrous material increases the surface area at the absorbing area and also does not allow dust particles to enter due to the presence of fibrous material.

The goal of our project is to increase the efficiency of the collector. Fins are one of the most effective ways to increase the efficiency of the collector. Fins are certain protrusions or extra surfaces present along the channel which will increase the surface area of the channel. This will increase the heat transfer coefficient between the absorber plate and glass cover thus improving the efficiency. There has immense research on different types of fins.

Wei Chang et al, created a solar air collector with finned absorber with a single channel is researched and theoretical values are decided. He found out that efficiency varies in the range of $3 \%$ at a different angle. For varying mass flow rate, varying efficiencies were obtained. The other way of increasing the efficiency of solar air collectors is to use a certain material for storing the heat. S.S. Krishnananth and K.Kalidasa Murugavel, used paraffin wax as a thermal storage medium. They applied the paraffin wax in the absorber system which undergoes a phase change. There were paraffin capsules present in a different place. Abhishek Saxena et al used desert sand as heat storage. The desert sand is used as heat absorbing material. He powered it using a halogen lamp. This enhanced efficiency.

We can alter the geometry, shape or position of the fins in the absorber channel. Foued Chabane et al, $\mathrm{He}$ 
added hollow longitudinal fins on the absorber plate to increase the heat exchange area. The efficiency of the one using the longitudinal fins were $5.83 \%$ than the one without fins. The efficiency of the one with the normal fins was $5.1 \%$ more than the one without the fins. Different modifications can be made to the absorber by adding different geometries of fins, like circular, rectangular, rectangular and circular together at different positions. The fins can be placed at the top or bottom of the channel or across the channel without reducing the area of the cross-section of the channel to a large extent. Many other fins like louvered fins are also used. Subhash Chand and Prabha Chand, did a parametric study on the efficiency calculation of solar air heater equipped with louvered fins. The thermal efficiency increased from $43.14 \%$ to $76.79 \%$. R Kashyap et al, did a thermal performance analysis on the perforated fin on solar air heater. The collector efficiency for the perforated pin increased. The outlet temperature also increased from $329 \mathrm{~K}$ to $340 \mathrm{~K}$ which is a result of enhanced solar intensity. Nguyen Xuan and Le Minh Nhut, added internal crimped fins in the solar air collectors, they used seven internal crimped fins which used increased the collector area by $2 \mathrm{~m} 2$. The result is, it extends the air time and increases the turbulent air flow. There are a lot of vortices present which are present in the geometry of the wings causes a lot of heat losses. Many of the performance parameters are increased such as solar radiation intensity and ambient temperature.

In this project, we are planning to use helical tapes as the heat transfer enhancing device. Solar air heaters use helical tubes for transferring heat. It was decided to use helical tapes due to the change of the flow pattern of air. Due to the presence of its rectangular crosssection, it will alter the movement of air in the system. Any change in the flow pattern of fluid will have a direct effect on the flow parameters such as Reynolds Number, efficiency. We are planning to add the curved helical tapes adjacent to the vertical fins. The helical pattern will touch the adjacent vertical fins of the channel by curving through. The experimental setup will be set up and comparative analysis will be done by the second review. The material of the helical tapes used will be Aluminium because of its light weight and ease of manufacturability. Since iron and other materials have weight constraints and have less resistance to corrosion, they are infeasible for this process. We will take down observations and will perform calculations to know whether helical tapes are the best to adopt.

\section{EXPERIMENTAL FACILITY}

\subsection{Setup}

The solar air heater setup consists of a rectangular box which has an inlet on one side and outlet on the other side. The top of the box consists of an absorber plate and a glass plate above that. The inlet of the heater is connected with a blower. The blower blows air through the inlet and flows out through the outlet.

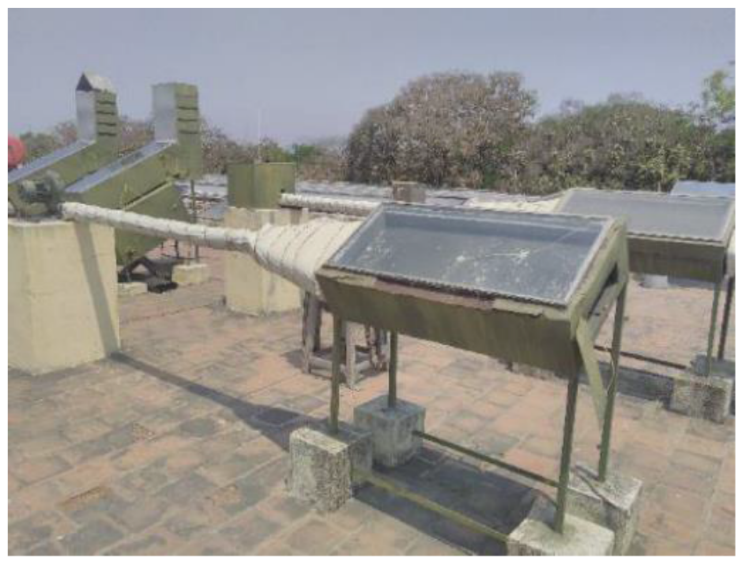

Figure 1: Solar air heater with a glass plate and absorber plate with an inlet connected to blower and outlet on the other end.

Inside the air heater, there are rectangular vertical fins present along with the flow of the channel. The air flows through the spaces between the fins. These fins increase the surface area for heat transfer. Due to the presence of the fin, it changes the flow of the air.

The system is modified by adding seven pairs of helical fins with a rectangular cross-section. The part was fabricated in the workshop and installed in between the spaces of the vertical fins. The helical fins were placed without touching the top and bottom surfaces. The length of the helical fins is the length of the air heater.

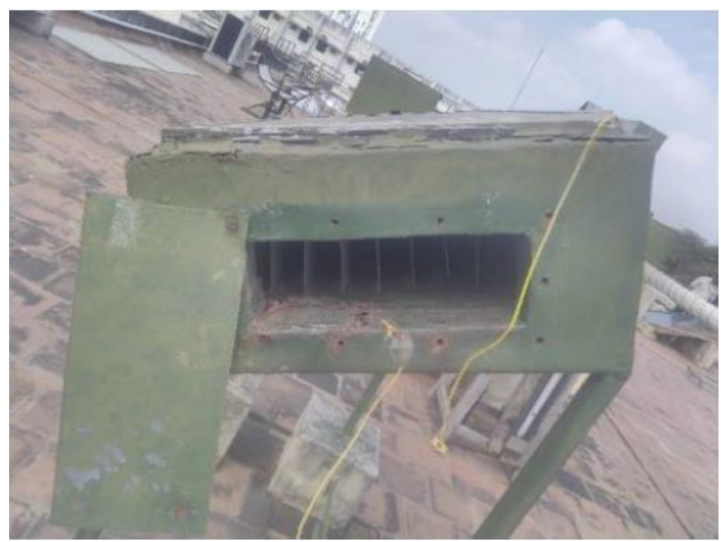

Figure 2: Solar air heater outlet view with vertical fins. (side view). 


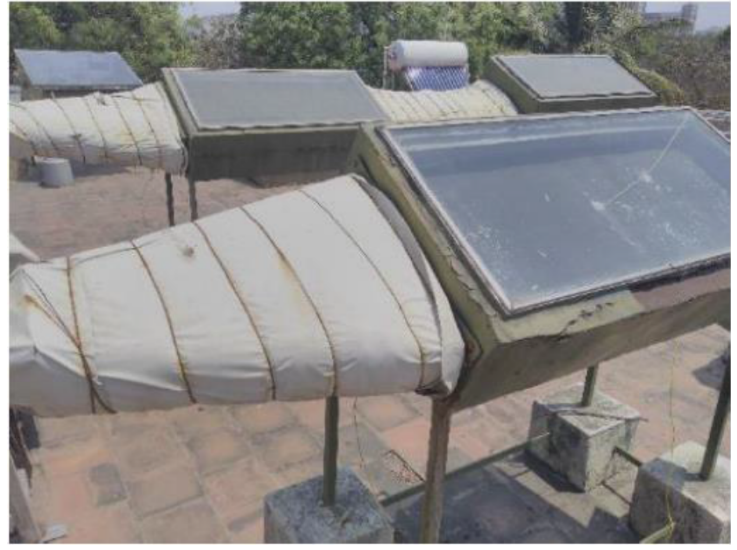

Figure 3: Inlet connected to the blower.

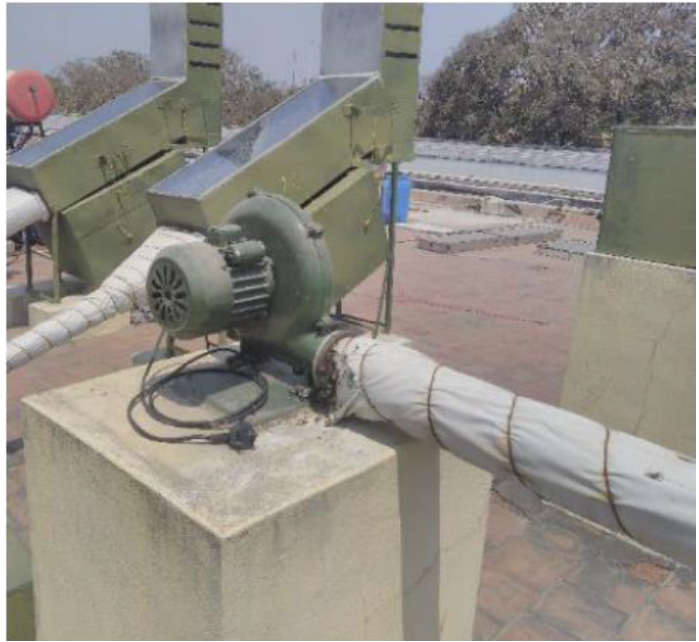

Figure 4: Blower connected to the inlet.

Before installing the helical fins, a few sets of readings without the helical fins were taken. We connected a multimeter with the inlet and outlet and measured temperature at these points. The pyranometer which measures the sun's radiation is also connected to a voltmeter to observe the voltage and measure the change in solar radiation. After installing the helical fins, the setup is run to get the new readings.

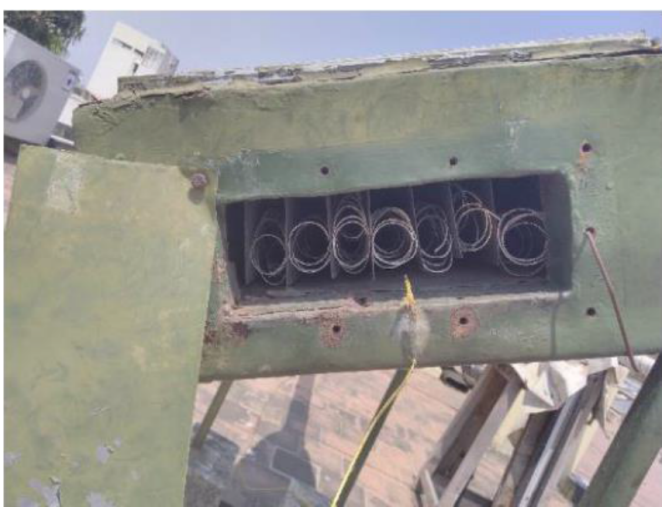

Figure 5: Helical fins attached (outlet view).

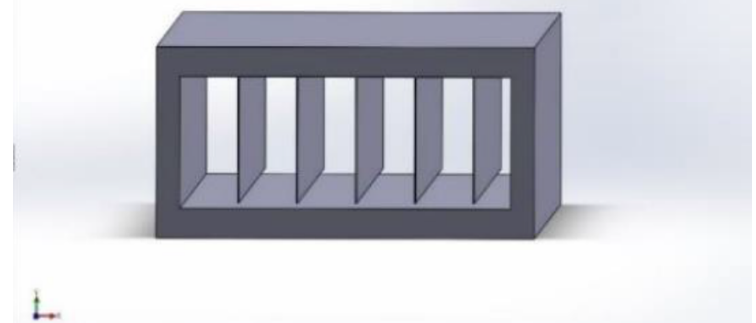

Figure 6: SolidWorks model ofexisting apparatus.

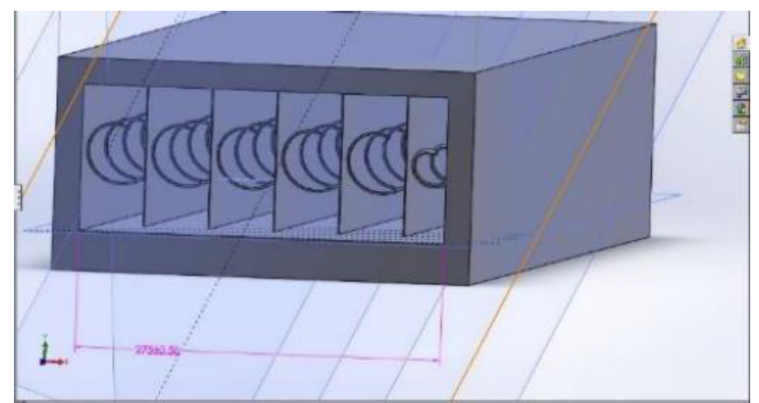

Figure 7: SolidWorks model of solar air heater with helical fin.

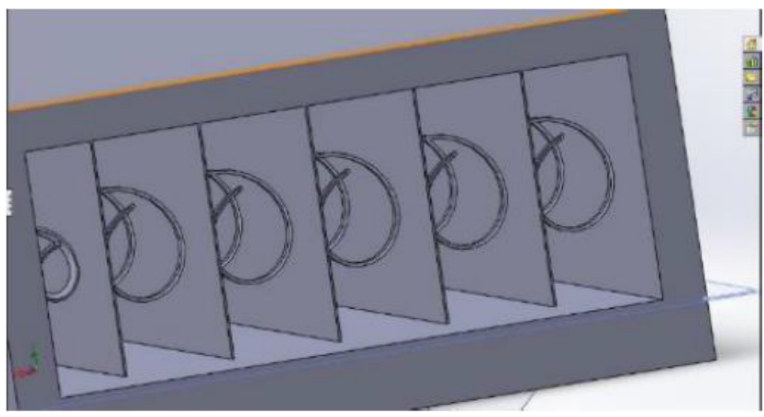

Figure 8: Close-up view of solar air heater with helical fin.

\section{MEASUREMENTS}

The pyranometer measures the amount of radiation hitting the solar air heater. A voltmeter is connected to the pyranometer and the voltage is noted down. The experiment is conducted between 10:36 a.m. to $11: 16$ a.m. with a sampling interval of 3 hours and the next set from $14: 18$ p.m. to $14: 58$ p.m. During the following periods, the values were taken down every $10 \mathrm{~min}$ to observe the change in temperature. The following formula converts to $\mathrm{W} / \mathrm{m} 2$.

Solar flux, $I=$ (pyranometer reading $m V * 1000$

*10/12.56

Mass flow rate $m,=\rho A V$

Where

$\rho$ is the density of air 
$A$ is an area of cross-section

$\mathrm{V}$ is the velocity of air flowing

The efficiency of the solar air heater can be calculated using the following formula:

Efficiency,

$$
E f f .=(m c p(T o-T i)) /(I * A)
$$

Where,

$\mathrm{m}$ is the mass flow rate

$c p$ is specific heat

To is outlet temperature

$T i$ is inlet temperature

A is the area of the duct.

Reynolds Number, $\operatorname{Re}=(\rho \mathrm{VD}) / \mu$

Where,

Hydraulic Diameter, $D=\left(4^{*} A\right) / P=0.1432$

Nusselt Number,

$N u=0.453 *, \operatorname{Re} 0.5 * \operatorname{Pr} 0.33$

Where,

$\operatorname{Pr}$ is Prandtl Number, $\operatorname{Pr}=0.7$

$\mathrm{Nu}=\mathrm{hD} / \mathrm{k}$

Where,

$\mathrm{h}$ is convective heat transfer coefficient, $W / m 2 \mathrm{~K}$

$\mathrm{k}$ is coefficient of thermal conductivity, W/m K

Dynamic Viscosity,

$\mu=-\left(-1.1555 \mathrm{E}-14^{*}(\text { Temperature })^{*} 3\right)+(9.5728 \mathrm{E})$ -

$\left(11^{*}(\text { Temperature })^{*} 2\right)+(3.7604 \mathrm{E})-\left(8^{*}(\right.$ Temperature $\left.)\right)$ 3.4484E-6)

Deviation between experimental value and theoretical value can be found using this formula,

Error $\%=(($ Average Experimental outlet temperature- Theoretical outlet temperature)/ Theoretical outlet temperature $)^{*} 100$

\section{RESULTS AND DISCUSSIONS}

Based on the formulas above, theoretical and experimental analysis is done. The comparison between the original equipment and the modified equipment is also graphed to understand the temperature difference.

The experimental analysis is also done to understand the relation between theoretical and experimental. The values that have been noted for almost a day. The first five values have been taken in the morning over regular intervals. The next five values have been noted down during the afternoon. The experiment has been done twice, for the existing apparatus and the improved apparatus.

This helps us draw conclusions based on the changes noted due to the addition of the modification to the apparatus. The values are noted down in a tabular format with the efficiencies mentioned in each process.

The error analysis done is between the experimental and theoretical values of both the setups. The theoretical values are acquired from ANSYS analysis.

Through the ANSYS analysis, it is found out that the theoretical value for existing setup is 44-celsius degrees and for the improved setup is 46-celsius degrees.

The measurements and initial conditions of the solar air heater are as follows:

1. Length of the channel in a solar air heater: $1 \mathrm{~m}$

2. Breadth of the absorber plate in the solar air heater: $0.5 \mathrm{~m}$

3. Length of the vertical fins: $10.5 \mathrm{~cm}(0.1 \mathrm{~m})$

4. Width of each tape: $1 \mathrm{~mm}(0.001 \mathrm{~m})$

5. Number of vertical fins: 6

6. Inlet area: $27.5 \mathrm{~cm} \times 9.5 \mathrm{~cm}$

7. Air mass flow rate: $10.28 \mathrm{~kg} / \mathrm{s}$

The length measurements of the helical tapes attached are as follows:

1. Since the spaces between the different vertical fins in the existing setup are unequal, the 
Table 1: Existing Setup Temperature and Efficiency Values

\begin{tabular}{|c|c|c|c|c|c|c|}
\hline $\begin{array}{l}\text { Time (24 } \\
\text { hr format) }\end{array}$ & $\begin{array}{c}\text { Inlet Temperature } \\
\text { (Celsius degrees) } \\
\text { (Ti) }\end{array}$ & $\begin{array}{c}\text { Outlet Temperature } \\
\text { (Celsius degrees) } \\
(T o)\end{array}$ & $\begin{array}{l}\text { Pyranometer } \\
\text { reading }(\mathrm{mV})\end{array}$ & $\begin{array}{l}\text { Solar radiation } \\
(\mathrm{W} / m 2)(\mathrm{S})\end{array}$ & $\begin{array}{c}\text { Temperature rise } \\
\text { parameter }(T o-T i) / S \\
\text { (celsius degree } \mathrm{m} 2 / \mathrm{W})\end{array}$ & $\begin{array}{c}\text { Efficiency } \\
(\%)\end{array}$ \\
\hline $10: 36$ & 35.2 & 42.9 & 7.9 & 628.98 & 0.012 & 48.41 \\
\hline $10: 46$ & 36.9 & 43.6 & 8.1 & 644.9 & 0.01 & 42.1 \\
\hline $10: 56$ & 37.6 & 43.8 & 8.2 & 652.86 & 0.009 & 37.5 \\
\hline 11:06 & 37.8 & 44.1 & 8.3 & 660.82 & 0.0095 & 37.7 \\
\hline $11: 16$ & 38.2 & 44.0 & 8.5 & 676.75 & 0.0085 & 33.8 \\
\hline $14: 18$ & 40.2 & 44.3 & 8.7 & 692.67 & 0.0059 & 21.6 \\
\hline $14: 28$ & 40.9 & 44.2 & 8.8 & 700.63 & 0.0047 & 18.6 \\
\hline $14: 38$ & 40.3 & 44.3 & 8.7 & 692.67 & 0.0057 & 22.6 \\
\hline $14: 48$ & 40.6 & 43.9 & 8.9 & 08.59 & 0.0046 & 18.4 \\
\hline $14: 58$ & 40.7 & 43.8 & 8.9 & 708.59 & 0.0043 & 17.3 \\
\hline
\end{tabular}

Average of the Outlet Temperature $=(42 \cdot 9+43 \cdot 6+43.8+44 \cdot 1+44 \cdot 0+44 \cdot 3+44 \cdot 2+44 \cdot 3+43 \cdot 9+43 \cdot 8) / 10=43 \cdot 89$

Error from the original theoretical value $=((\text { Theoretical value- Experimantal value }) / \text { Theoretical value })^{*} 100$

$$
\begin{aligned}
& =((44-43.89) / 44)^{*} 100 \\
& =0.25 \%
\end{aligned}
$$

Table 2: Heat Transfer Table

\begin{tabular}{|c|c|c|c|c|}
\hline $\begin{array}{c}\text { Time (24 hr } \\
\text { format) }\end{array}$ & $\begin{array}{c}\text { Viscosity }(\boldsymbol{\mu}) \mathbf{x} \mathbf{1 0 - 6} \\
\mathbf{( N s / m 2 )}\end{array}$ & $\begin{array}{c}\text { Reynold's Number } \\
(\mathbf{R e})\end{array}$ & $\begin{array}{c}\text { Nusselt } \\
\text { Number (Nu) }\end{array}$ & $\begin{array}{c}\text { Heat transfer coefficient (h) } \\
(\mathbf{W} / \mathbf{m} 2 \boldsymbol{K})\end{array}$ \\
\hline \hline $10: 36$ & 1.82697 & 2569 & 20.41 & 3.848 \\
\hline $10: 46$ & 1.80052 & 2565 & 20.39 & 3.844 \\
\hline $10: 56$ & 1.79296 & 2563 & 20.38 & 3.840 \\
\hline $11: 06$ & 1.78162 & 2561 & 20.37 & 3.840 \\
\hline $11: 16$ & 1.7854 & 2562 & 20.38 & 3.840 \\
\hline $14: 18$ & 1.77406 & 2557 & 20.36 & 3.838 \\
\hline $14: 28$ & 1.77784 & 2558 & 20.36 & 3.838 \\
\hline $14: 38$ & 1.77406 & 2557 & 20.36 & 3.838 \\
\hline $14: 48$ & 1.78918 & 2562 & 20.35 & 3.836 \\
\hline $14: 58$ & 1.79296 & 2563 & 20.38 & 3.840 \\
\hline
\end{tabular}

diameter of the helical tapes is different We took the diameter of the helical fin to be $4.0 \mathrm{~cm}$ after consultation with project guide and fabricator as it would be the optimal dimension.

2. Rectangular cross-section of fin: $1.5 \mathrm{~mm} \times 4 \mathrm{~mm}$

3. Pitch: $100 \mathrm{~mm}$
4. Length of the helical fin: $100 \mathrm{~cm}$

5. Number of revolutions: 10

6. Start angle: 64 deg

7. Material: Aluminium 
Table 3: Experimental Values of solar air Heater with Helical Tapes

\begin{tabular}{|c|c|c|c|c|c|c|}
\hline $\begin{array}{l}\text { Time (24 } \\
\text { hr format) }\end{array}$ & $\begin{array}{l}\text { Inlet Temperature (Ti) } \\
\text { (celsius degrees) }\end{array}$ & $\begin{array}{l}\text { Outlet Temperature } \\
\text { (To) (celsius degrees) }\end{array}$ & $\begin{array}{l}\text { Pyranometer } \\
\text { Reading } \\
\text { (mV) }\end{array}$ & $\begin{array}{l}\text { Solar } \\
\text { radiation } \\
(\mathrm{W} / \mathrm{m} 2)\end{array}$ & $\begin{array}{c}\text { Temperature rise } \\
\text { parameter }(\text { To-Ti)/l } \\
\text { (celsius degree } \mathrm{m} 2 / \mathrm{W} \text { ) }\end{array}$ & $\begin{array}{c}\text { Efficiency } \\
(\%)\end{array}$ \\
\hline $10: 36$ & 35.2 & 43.8 & 7.9 & 628.98 & 0.013 & 54.7 \\
\hline $10: 46$ & 36.8 & 44.1 & 8.1 & 644.9 & 0.011 & 44.76 \\
\hline $10: 56$ & 37.7 & 44.4 & 8.3 & 660.82 & 0.01 & 40 \\
\hline 11:06 & 37.9 & 44.8 & 8.4 & 668.78 & 0.01 & 40.8 \\
\hline $11: 16$ & 38.1 & 44.7 & 8.5 & 676.75 & 0.0097 & 38.56 \\
\hline $14: 18$ & 40.2 & 45.2 & 8.7 & 692.67 & 0.0072 & 28.5 \\
\hline $14: 28$ & 40.8 & 45.6 & 8.8 & 700.63 & 0.0068 & 27.09 \\
\hline $14: 38$ & 40.4 & 45.7 & 8.7 & 692.67 & 0.0076 & 30.2 \\
\hline $14: 48$ & 40.7 & 46.1 & 8.8 & 700.63 & 0.0077 & 30.4 \\
\hline $14: 58$ & 40.8 & 45.8 & 8.8 & 700.63 & 0.00710 & 28.2 \\
\hline
\end{tabular}

Average of the Outlet Temperature $=(43.8+44.1+44.4+44.8+44.7+45.2+45.6+45.7+46.1+45.8) / 10=45 \cdot 02$

Error from the original theoretical value $=((\text { Theoretical value- Experimantal value }) / \text { Theoretical value })^{*} 100$

$$
\begin{aligned}
& =((46-45.02) / 46)^{*} 100 \\
& =2.13 \%
\end{aligned}
$$

Table 4: Heat Transfer Table

\begin{tabular}{|c|c|c|c|c|}
\hline Time (24 hr format) & $\begin{array}{c}\text { Viscosity }(\boldsymbol{\mu}) \\
\mathbf{x} \mathbf{1 0 - 6}\end{array}$ & Reynold's Number (Re) & Nusselt Number (Nu) & $\begin{array}{c}\text { Convective heat transfer } \\
\text { coefficient (h) (W/m2 K) }\end{array}$ \\
\hline \hline $10: 36$ & 1.79296 & 2563 & 20.38 & 3.842 \\
\hline $10: 46$ & 1.78162 & 2561 & 20.37 & 3.840 \\
\hline $10: 56$ & 1.77028 & 2557 & 20.36 & 3.838 \\
\hline $11: 06$ & 1.75516 & 2554 & 20.35 & 3.836 \\
\hline $11: 16$ & 1.75894 & 2554 & 20.35 & 3.836 \\
\hline $14: 18$ & 1.74004 & 2550 & 20.33 & 3.833 \\
\hline $14: 28$ & 1.72493 & 2549 & 20.32 & 3.833 \\
\hline $14: 38$ & 1.72115 & 2547 & 20.31 & 3.831 \\
\hline $14: 48$ & 1.70603 & 2546 & 20.32 & 3.829 \\
\hline $14: 58$ & 1.71737 & 2547 & & \\
\hline
\end{tabular}

The inlet temperature has been mentioned in the above Figure 10. to show the magnitude of change between the inlet and outlet temperature in both the cases.

\section{CONCLUSIONS}

From the above graphs and tabulations, it is evident that the efficiency has improved with the help of helical tapes. In the Figure 8, the time vs efficiency graph is plotted and the graph shows there is a higher efficiency for the solar air heater with helical tapes.

From the Figure 11, it is also noticed that the outlet temperature has been increased using the helical tapes. This shows that with the use of helical tapes can increase the outlet air temperature. 


\section{a) Time Vs Efficiency}

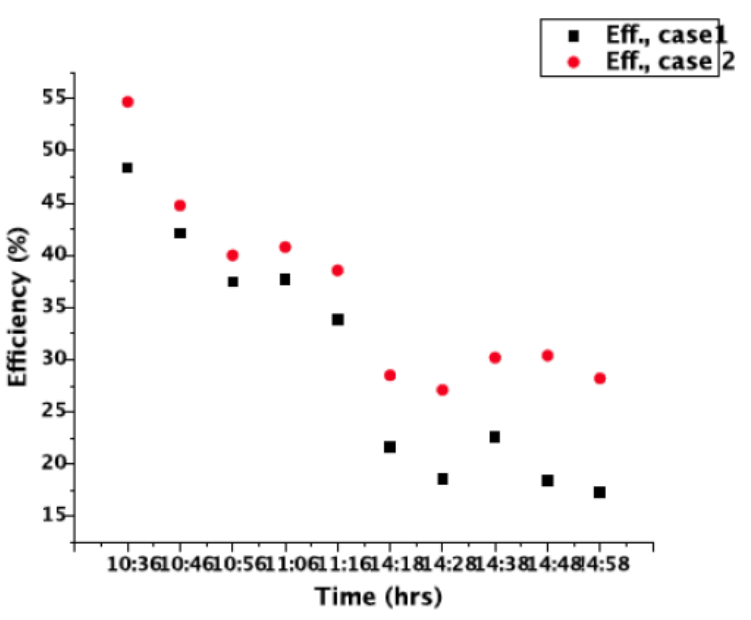

Figure 9: Comparison between solar air heater with and without helical tapes (Time Vs Efficiency).

b) Time Vs Temperature graph

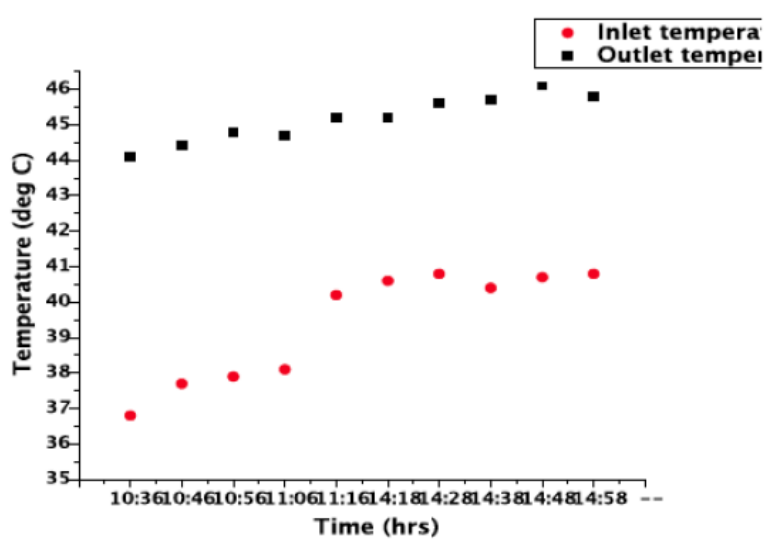

(a)

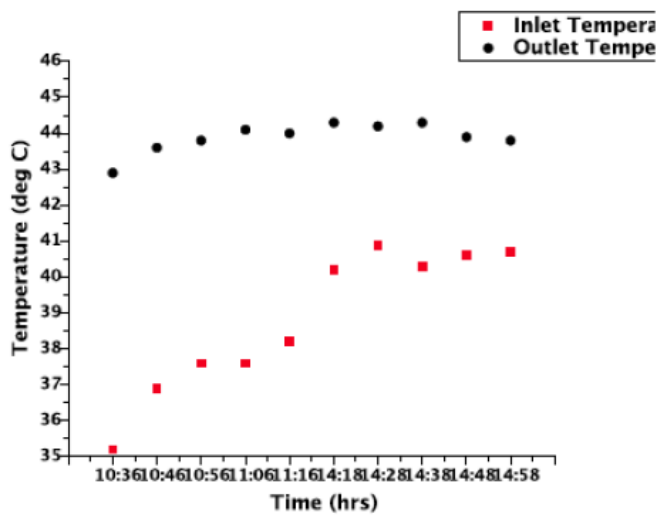

(b)

Figure 10: Time Vs Temperature graph for the setup (a) without helical tapes and (b) setup with helical tapes

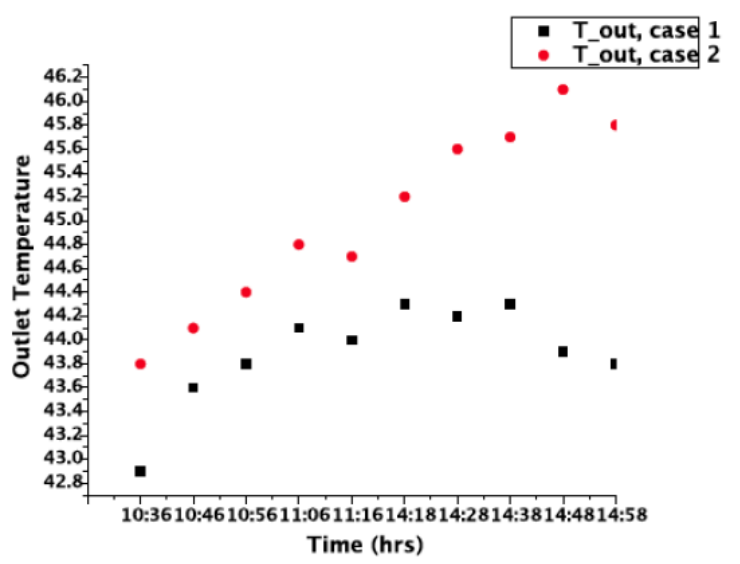

Figure 11: Comparative analysis between Time and Outlet temperature for both setups.

\section{c) Temperature rise parameter $\mathrm{Vs}$ Efficiency}

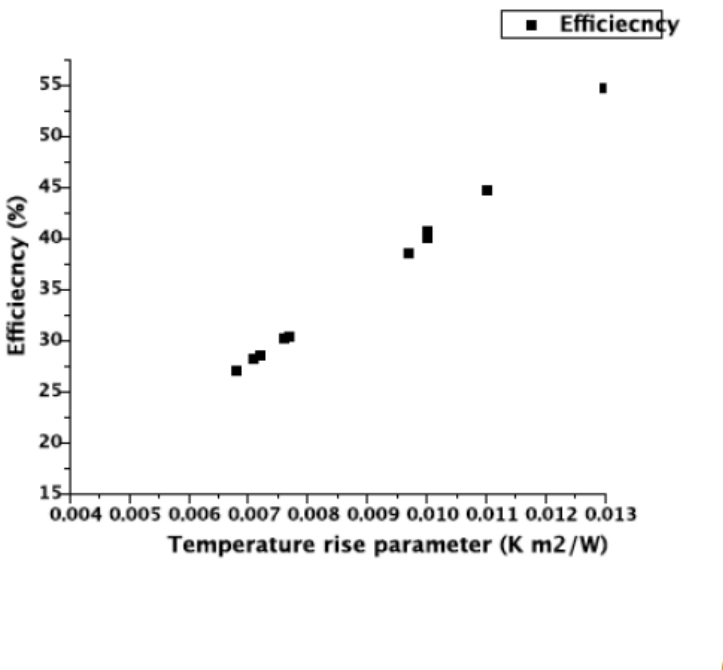

(a)

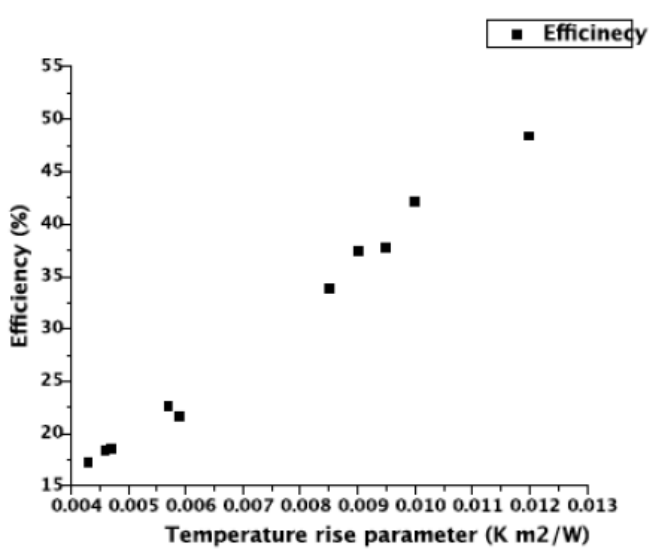

(b)

Figure 12: Temperature rise parameter Vs Efficiency for the setup (a) without helical tapes and (b) setup with helical tape. 


\section{d) Absorber plate temperature Vs Intensity}

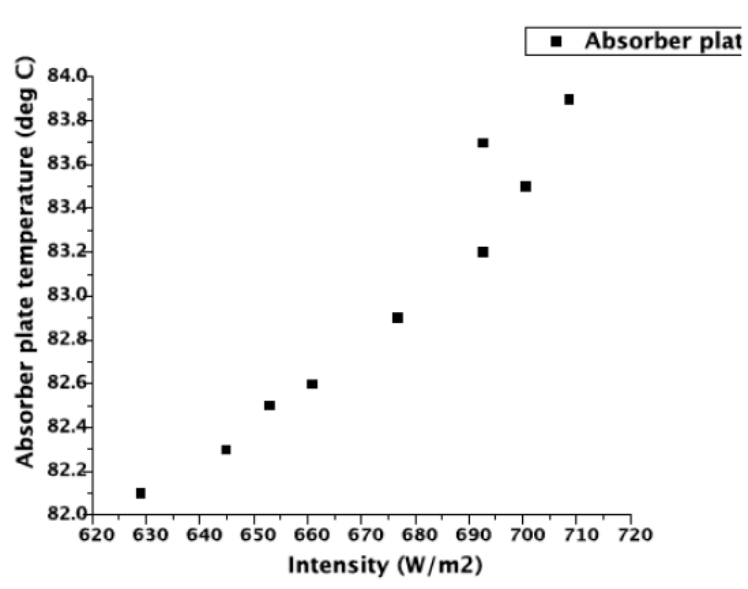

(a)

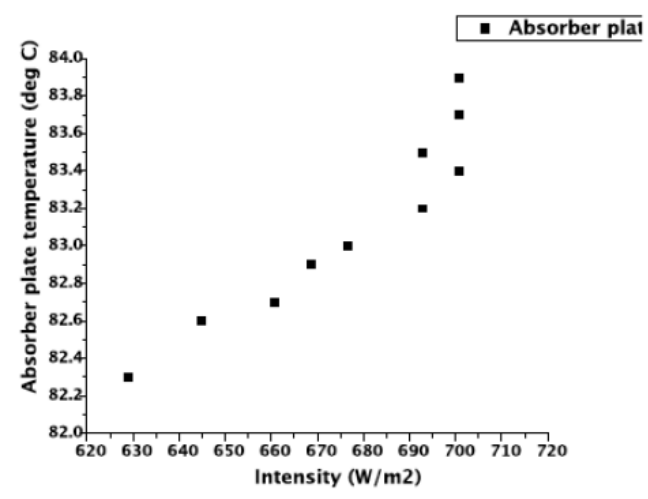

(b)

Figure 13: Absorber plate temperature Vs Intensity for setup (a) without helical tapes and (b) setup with helical tapes.

\section{e) Time Vs Viscosity}

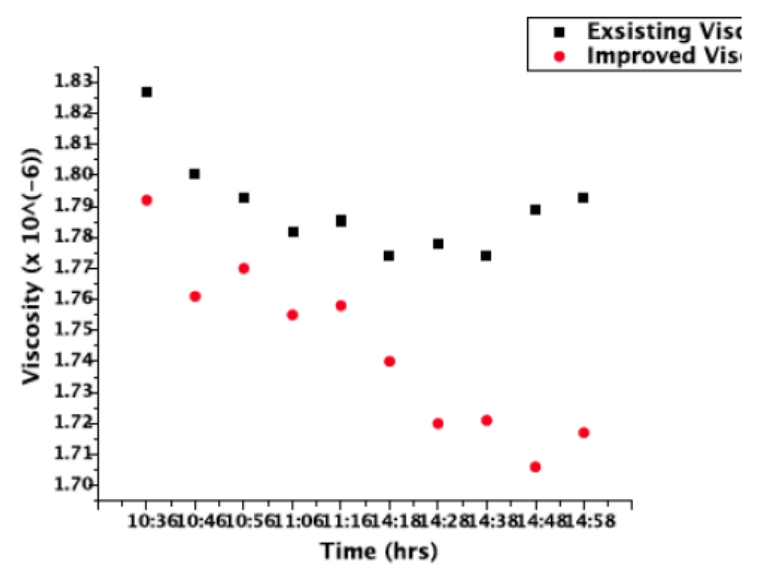

Figure 14: Comparative analysis between both the setups.

\section{f) Time Vs Convective heat transfer coefficient}

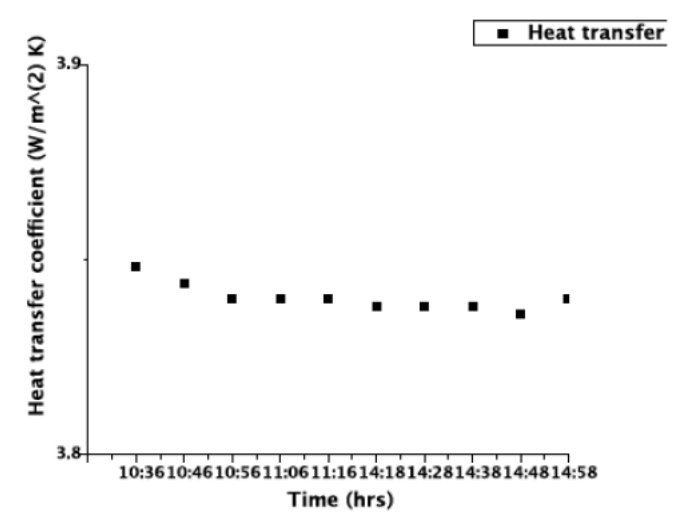

(a)

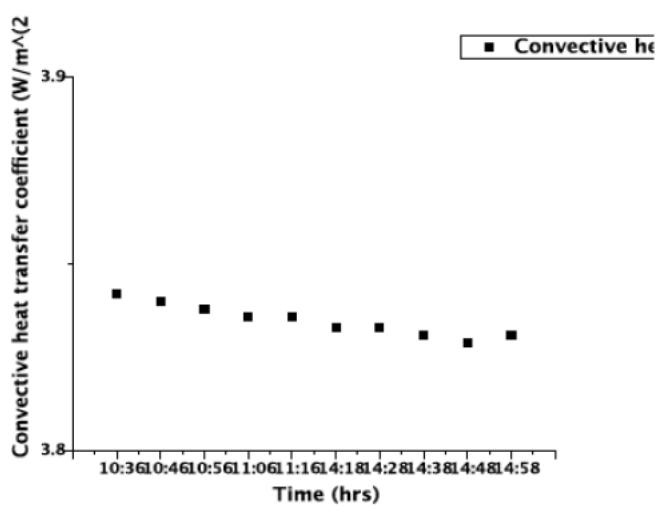

(b)

Figure 15: Time Vs Convective heat transfer coefficient for solar air heater (a) without and (b) with helical tapes.

The rise in temperature of the air in the solar air heater has been in correspondence with the increased efficiency which is visible in Figure 12. This further proves that the solar air heater with helical tapes is the best option.

The average efficiency has improved by approximately $10 \%$ as tabulated in Tab 1 and Tab 3 . In time interval 14:38, 14:48, 14: 58-time intervals the efficiency comparison between the inlet and outlet temperature shows a $10 \%$ or above increase in efficiency. While some other intervals like 11:06 the increase in efficiency is $2.5 \%$.

Although the average efficiency was improved by approximately $10 \%$, the convective heat transfer coefficient remains almost constant at $3.84 \mathrm{~W} / \mathrm{m}^{\wedge} 2 \mathrm{~K}$ with a negligible increase for helical tapes with a pitch of $100 \mathrm{~mm}$ which is indicated in the above graphs, Figure 15. 


\section{ACKNOWLEDGMENTS}

This project is supported by VIT University. I received immense help from my project guide. Mr. Raja Sekhar Y. The infrastructure that VIT provided in the form of labs and providing the space to fabricate the helical tapes, helped in the successful completion of the project.

\section{NOMENCLATURE}

$m$ meter

$\mathrm{cm}$ Centimeter

m mass flow rate

cp specific heat

$\mathrm{mV}$ millivolt

To outlet temperature

$\mathrm{Ti}$ inlet temperature

A area of the duct.

$\mathrm{Nu}$ Nusselt Number

h convective heat transfer coefficient

k thermal conductivity of solid

$\mathrm{L} \quad$ Length of channel

celsius degrees degree Celsius

Eff. Efficiency

\section{REFERENCES}

[1] Raja Sekhar, Sharma and Basaveswara Rao2, Evaluation of heat loss coefficients in solar flat plate collectors, ARPN Journal of Engineering and Applied Sciences, 2009; 4(5): 1519 , pp. $753-762$.
Ali Daliran and Yahaya Ajabshirchi (2018), Theoretical and experimental research on the effect of fins attachment on operating parameters and thermal efficiency of solar air collector, Information Processing in Agriculture, 2018; 5(4): 411-421. https://doi.org/10.1016/j.inpa.2018.07.004

[3] Ganesh Badgujar, Sachin Nimbulkar and Rajesh Dahibhate Experimental Investigations on Solar Flat plate collector by changing geometry of fin, MAYFEB Journal of Mechanical Engineering, 2017; 2: 52-62

[4] Li, Paul, Sellami, Mallick, A.R. Knox, Natural convective heat transfer in a walled CCPC with PV cell, Case Studies in Thermal Engineering 2017; 10: 499-516. https://doi.org/10.1016/j.csite.2017.10.009

[5] Abd Elnaby Kabeel, Mofreh Ahmed, Omara, Kandeal (2016), Solar air heaters: Design configurations, improvement methods and applications, Renewable and Sustainable Energy reviews, December 2016

[6] Krishnananth, Kalidasa Murugavel, Experimental study on double pass solar air heater with thermal storage, Journal of King Saud University- Engineering Sciences, 2012; 25(2): 2013; 135-140 https://doi.org/10.1016/j.jksues.2012.05.004

[7] Foued Chabane, Noureddine Moummi, Said Benramache (2013), Experimental study of heat transfer performance with longitudinal fins of solar air heater, Journal of Advanced Research 2014; 5(2): 183-192 https://doi.org/10.1016/j.jare.2013.03.001

[8] Wei Chang, Yunfung Wang, Ming Li, Xi Luo, Yongbao Ruan, Yongrui Hong, Shaobo Zhang, The theoretical and experimental research on thermal performance of solar air collector with finned absorber, Energy Procedia, May 2015; 70: $13-22$ https://doi.org/10.1016/j.egypro.2015.02.092

[9] Subhash Chand and Prabha Chand (2018), Parametric study on performance of solar air heater equipped with louvered fins, Journal of Medical Science and Technology, August 2018 https://doi.org/10.1007/s12206-018-0747-y

[10] Kashyap and Singh and Kumar and Roy (2018), Thermal performance analysis of perforated pin fin solar air heater International Conference on Mechanical, Materials and Renewable Energy https://doi.org/10.1088/1757-899X/377/1/012200

[11] Nguyen Xuan Lam and Le Minh Nhut, Experimental Study on Solar Air Collector with Internal Crimped Fins, International Journal of Energy and Power Engineering 2018; 7(2): 19-26 https://doi.org/10.11648/j.ijepe.20180702.11

Received on 18-4-2019

Accepted on 2-5-2019

Published on 2-5-2019

DOI: http://dx.doi.org/10.31875/2410-2199.2019.06.3

(c) 2019 John and Harikrishnan; Zeal Press.

This is an open access article licensed under the terms of the Creative Commons Attribution Non-Commercial License (http://creativecommons.org/licenses/by-nc/3.0/), which permits unrestricted, non-commercial use, distribution and reproduction in any medium, provided the work is properly cited. 